\title{
Statin Ameliorates Coronary Perivascular Fibrosis in Chronic Kidney Disease: An Experimental Study
}

\author{
Putu N. Cahyawati, Sri A. Aryastuti, Putu D. Witari
}

Department of Pharmacology and Pharmacy, Faculty of Medicine and Health Sciences, Warmadewa University, Bali, Indonesia

\section{Background}

Cardiovascular disease is the major cause of morbidity and mortality in chronic kidney disease (CKD). Interstitial and perivascular fibrosis as a constant finding in heart biopsies in patients with CKD. The therapeutic strategies aimed to reduce cardiac fibrosis may provide a particular cardioprotective benefit in patients. The aim of this study was to determine whether treatment with simvastatin for 2 weeks would lead to change in collagen deposition on the heart in a mice model with CKD.

Methods

A total of 15 male swiss were used in this study. Chronic kidney disease was induced in the mice by $5 / 6$ subtotal nephrectomy. The animals were randomized into three groups: sham-operated ( $\mathrm{SO}, \mathrm{n}=5$ ), 5/6 subtotal nephrectomy (SN, $\mathrm{n}=5$ ) and $5 / 6$ subtotal nephrectomy followed by $20 \mathrm{mg} / \mathrm{kgBW}$ simvastatin (SIMV, $\mathrm{n}=5$ ). After 2 weeks, blood and heart were harvested for histologic analysis.

Results

Administration of simvastatin significantly improved creatinine serum on SIMV group $(0.49 \pm 0.09 \mathrm{mg} / \mathrm{dl})$ compared to SN group $(1.92 \pm 0.34 \mathrm{mg} / \mathrm{dl})$. The collagen deposition was also more significant on SIMV group $(8.95 \pm 0.65 \mathrm{mg} / \mathrm{dl})$ compared to SN group $(16.64 \pm 2.7 \mathrm{mg} / \mathrm{dl})$. The collagen deposition was more prominent on coronary perivascular than that on interstitial myocardial.

Conclusions

Administration of $20 \mathrm{mg} / \mathrm{kgBW}$ simvastatin significantly improved coronary perivascular fibrosis.

Keywords: simvastatin, coronary fibrosis, chronic kidney disease 